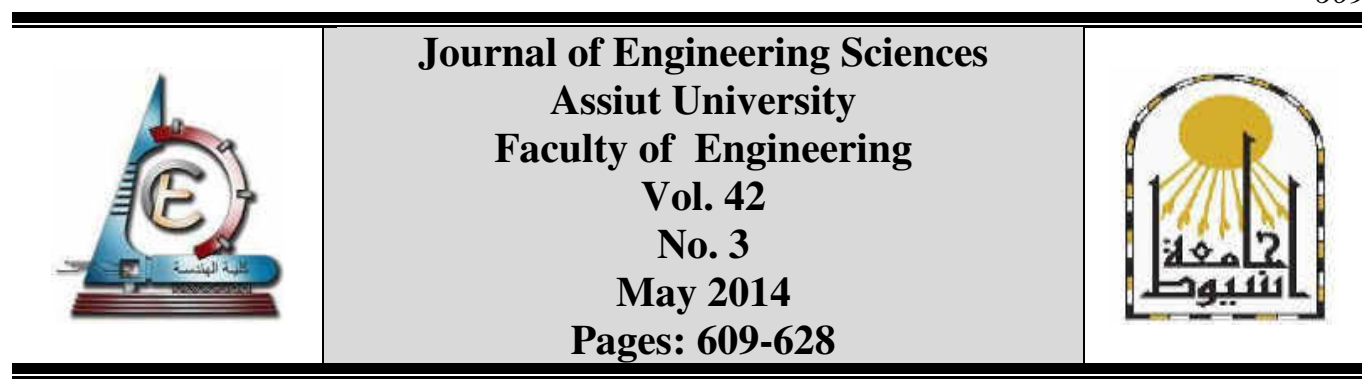

\title{
EFFECT OF SOME PARAMETERS ON PERFORMANCE OF DIRECT HIGH-RATE FILTRATION IN WATER TREATMENT
}

\author{
Haitham M. Amin ${ }^{1, *}$ and A. A. Mohamed ${ }^{2}$ \\ 1 Civil Engineering Dept., Faculty of Engineering, Al-Azhar University. \\ 2 Civil Engineering Dept., Faculty of Engineering, Assiut University. \\ Received 22 March 2014; revised 12 April 2014; accepted 17 April 2014
}

\begin{abstract}
Water filtration is a process for separating suspended or colloidal impurities from water by passage through a porous medium, usually a bed of sand or other medium. Direct filtration is a water treatment scheme that does not include separate in-plant sedimentation. It is not a new process but it is becoming increasingly important because of the safe drinking water. Water treatment plants are usually required to reduce filtered water turbidity down to 1 NTU. In this study, sand was used as a filtration media under constant direct high rate filtration conditions and performance. Turbidity removal performance and head loss were investigated as functions of filtration rate, bed depth, influent turbidity and media size. The filtration materials used in a downflow filter were sand and gravel. The sand bed thickness was changed from $60 \mathrm{~cm}$ to $120 \mathrm{~cm}$ with media size $1-2 \mathrm{~mm}$, while the gravel layer thickness was kept constant at $30 \mathrm{~cm}$. The influent raw water turbidity was varied from 10 to 30 NTU. The range of filtration rate was between 200 and $400 \mathrm{~m}^{3} / \mathrm{m}^{2} /$ day. From analysis and discussions of the experimental results, it was found that the depth of media has significant effect on the water quality and head loss, with the increasing of sand depth in the filter, both the water quality and the head loss increases. It was found that a sand depth of $120 \mathrm{~cm}$ is able to give a constant filtration rate from 200 to $400 \mathrm{~m}^{3} / \mathrm{m}^{2} /$ day with acceptable quality ( $\leq 1 \mathrm{NTU}$ ) for values of influent turbidity $\leq 10$ NTU.
\end{abstract}

Keywords: Direct filtration; turbidity removal; water treatment; high rate filtration

\section{Introduction}

Filtration is the passage of water through a porous medium for the removal of particles in suspension. Source water particles may include silt, clay, metal oxides, and organic fibers as well as a wide range of microorganisms, some of which are potentially harmful. Prominent biotic particles include 5 to $20 \mu \mathrm{m}$ algal microcolonies, 3 to $10 \mu \mathrm{m}$ protozoan cysts, and 0.2 to $2 \mu \mathrm{m}$ bacterial cells.

Total suspended solid is a measurement of water quality. Removal of suspended solid from water body has long been studied because of its adverse impacts on water quality. In

* Corresponding author.

E- mail address: prof_eng1010@yahoo.com 
order to manage natural resources of a water body through activities such as water quality control, prediction of suspended sediment concentration is very important. Therefore, controlling, measurement and the removal of suspended solids are absolutely vital for the clarity of water $[2,10]$. Turbidity is a darkness of water brought about by distinct particles such as suspended solids. One of the most important tests to enhance water quality control is turbidity estimation. The unit of turbidity from a calibrated nephelometer is called Nephelometric Turbidity Unit (NTU) $[4,11]$

Filtration is a process used in water treatment where solids are removed by physical and electrostatic means. The removal mechanisms are defined as transport, attachment, and detachment, where particles move through the filter media and attach by means of electrostatic forces. If the attachment bonds are not strong enough, or the pore size is not small enough for physical removal, some of the attached particles may detach. During effective filtration, most of these detached particles will reattach deeper in the filter [8].

Direct filtration is a water treatment scheme that does not include separate in plant sedimentation, it is one of several treatment processes that can be applied in combination with others to produce potable water. Low turbidity $(<30 \mathrm{NTU})$ and algae count in the order of $10^{6}$ units/liter among other factors were reported to suit the application of such process [9]. The substitution of conventional treatment scheme by direct filtration may increase significantly the cost savings (up to 30\%), because of the elimination of conventional flocculation and sedimentation processes [5].

Depth filtration is one of the most favorable particle separation means used universally in water and wastewater treatment processes. In this method, the particles are removed from its carrying fluid through a packed bed of granular or fibrous filter media by different mechanisms, such as transport, interception, aggregation, sedimentation and diffusion [6].

The media grain size, which affects the efficiency of filtration [3], is considered to be an indicator of the size of the particles that could be removed by the media [7]. The finer the sand, the smaller the particle size removed, and the better the quality of the filtration process, although a smaller size requires more frequent cleaning [14,7,13].

Suspended materials trapped by the filter decrease the water flow rate across the filter and eventually the sand media filter must be cleaned by backwashing, which is a critical part of media filter operation and performance [12]. Automatic backwashing can be controlled by time and/or by head loss across the filter.

\section{Experimental work}

The pilot filter system used in this study consists of two circular filter columns. A schematic of the filtration system is shown in Fig. (1). It contains four parts: a feeding tank, a sampling system, a controlling system and the filter column. The filter consists of a perspex column with an inside diameter of $10 \mathrm{~cm}$ and a height of $2.25 \mathrm{~m}$. It was partially filled with media taken from the full-scale plant filters.

The downflow filter was fed with raw water. The raw water was prepared by dispersing a known weight of dry kaolin clay $\left(\mathrm{Al}_{2} \mathrm{Si}_{2} \mathrm{O}_{5}(\mathrm{OH})_{4}\right)$, passing from sieve No.200 having a size $0.074 \mathrm{~mm}$ in tap water.

Bed depth (sand) was changed as $60,80,100$, and $120 \mathrm{~cm}$ with $30 \mathrm{~cm}$ gravel support. The specified effective size $\left(\mathrm{d}_{10}\right)$ of the sand was $1.05 \mathrm{~mm}$ with a uniformity coefficient $\left(d_{60} / d_{10}\right)$ of 1.24 . To measure the head loss, the filter was equipped with piezometers. The 
piezometers were located at the right side of the column, with one end penetrated into the lower end of media and the other end attached to the piezometers tubes. The average turbidity of the raw water during the study period was 10, 20, and $30 \mathrm{NTU}$, and filtration rate was 200,300 , and $400 \mathrm{~m}^{3} / \mathrm{m}^{2} /$ day.

The experimental runs were conducted under the conditions of a direct constant filtration rate during the filter run. The raw water was first pumped into the constant head tank with capacity of $5 \mathrm{~L} / \mathrm{sec}$. Overflow from it was discharged to the raw water tank. From the constant head tank, a 1.5" diameter main header pipe distributed the raw water into the two filter columns. The water level in the filter kept constant during all the runs. At the bottom of the column, the filter effluent went to the drain.

The head loss and the effluent turbidity were measured after times: zero, 0.5, 1 hour, after that for every one hour for the first 12 hours, and then every two hours throughout the remaining part of the run. The head loss, filter effluent turbidity, filter run length, and volume of filtered water were used to assess filter. The filter backwash was accomplished by using air scours followed by a water wash. Air and backwash water were introduced from the bottom of the column.

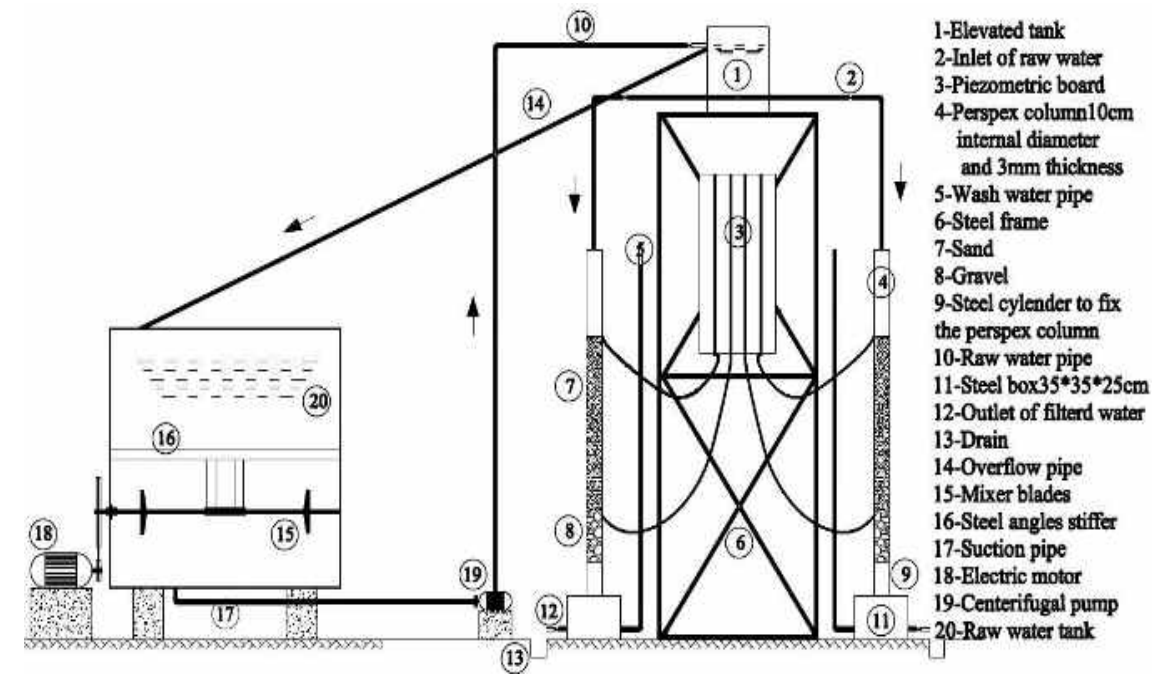

Fig. 1. Schematic diagram of the pilot filtration plant

\section{Results and discussion}

\subsection{Effluent turbidity}

Filtration rate, sand depth and influent water quality are the principal parameters that affect effluent quality.

\subsubsection{Effect of filtration rate}

To examine the effect of filtration rate on turbidity removal, Fig. (2) to Fig. (9) show the effect of different values of filtration rates on the turbidity removal. As shown in Fig. (5), depth $120 \mathrm{~cm}$ is able to give acceptable effluent turbidity $\leq 1$ NTU for filtration rate $\leq$ $400 \mathrm{~m}^{3} / \mathrm{m}^{2} /$ day and influent turbidity $10 \mathrm{NTU}$ after about 2 hours. For filtration rate $\leq 300$ $\mathrm{m}^{3} / \mathrm{m}^{2} /$ day sand depth $100 \mathrm{~cm}$ is able to give effluent turbidity $\leq 1 \mathrm{NTU}$ for influent turbidity $\leq 20$ NTU after about 2 hours as shown in Figures (4), (8). Also depth $80 \mathrm{~cm}$ is 
able to give acceptable effluent turbidity $\leq 1 \mathrm{NTU}$ for filtration rate $200 \mathrm{~m}^{3} / \mathrm{m}^{2} /$ day and influent turbidity 10 NTU after about 2 hours as shown in Fig. (3). From these Figures, it is clearly noticed that the effluent turbidity increases as the filtration rate increases.

Depositing particles in pores lead to a size reduction of pores, and therefore rises in local liquid velocity. The increasing velocity drags previously deposited particles from the filter bed, which then appear in the effluent. Furthermore, increasing flow rate increases the driving force, and this leads to higher amount of particulate matter being dragged to the effluent.

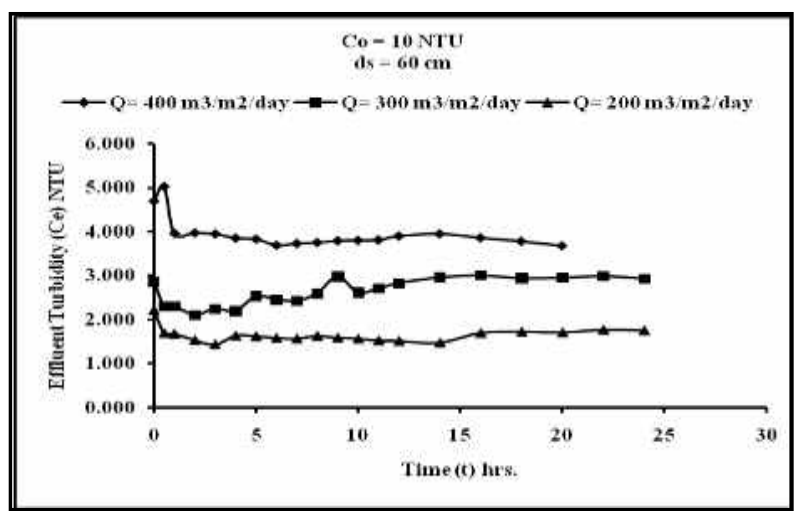

Fig. 2. Effect of filtration rate on the effluent turbidity at $\mathrm{ds}=60 \mathrm{~cm} \& \mathrm{Co}=10 \mathrm{NTU}$.

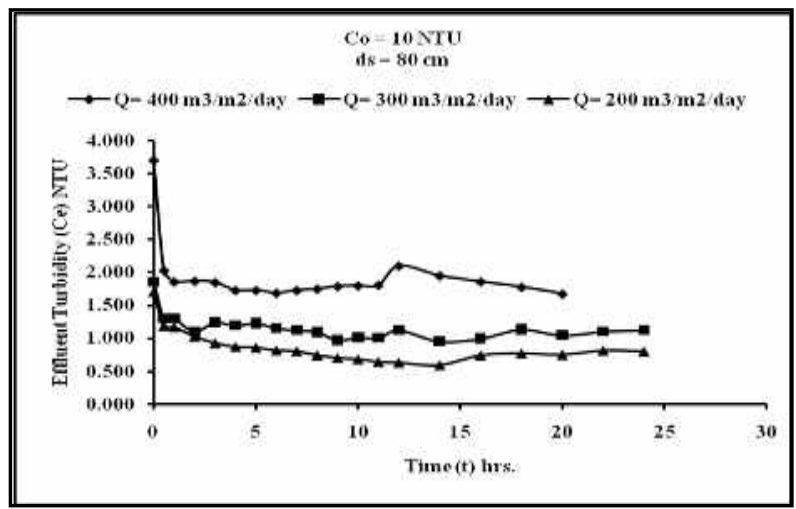

Fig. 3. Effect of filtration rate on the effluent turbidity at $\mathrm{ds}=80 \mathrm{~cm} \& \mathrm{Co}=10 \mathrm{NTU}$.

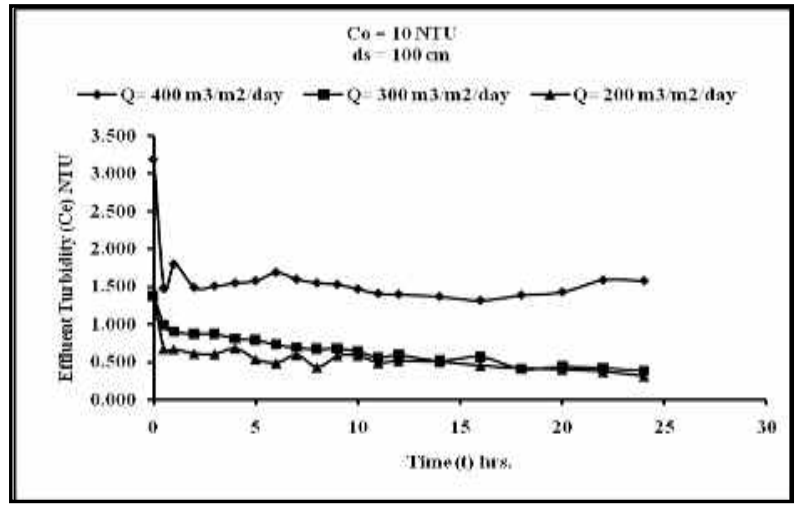

Fig. 4. Effect of filtration rate on the effluent turbidity at $\mathrm{ds}=100 \mathrm{~cm} \& \mathrm{Co}=10 \mathrm{NTU}$. 


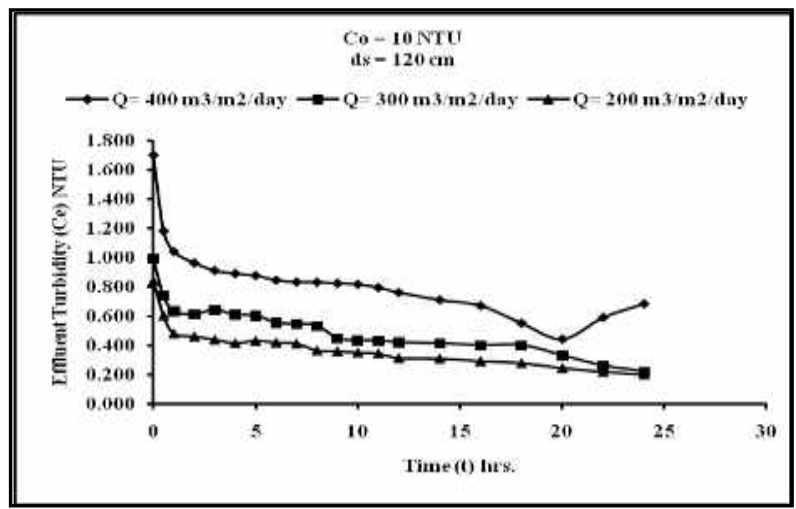

Fig. 5. Effect of filtration rate on the effluent turbidity at $\mathrm{ds}=120 \mathrm{~cm} \& \mathrm{Co}=10 \mathrm{NTU}$.

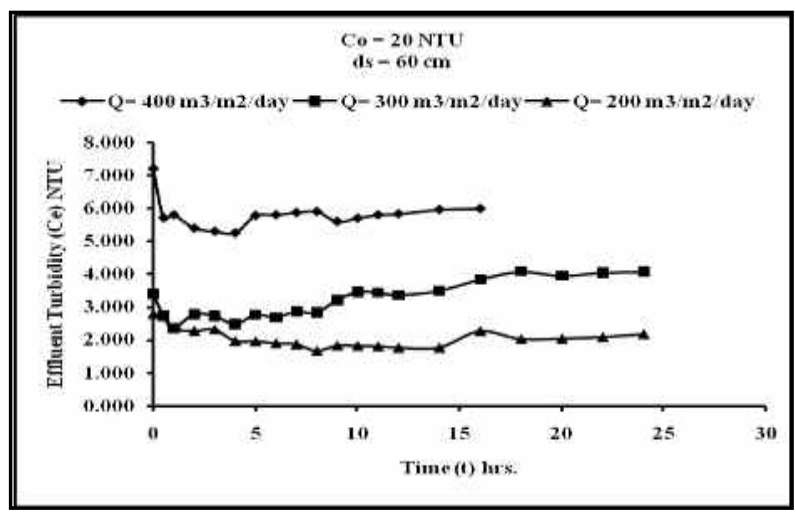

Fig. 6. Effect of filtration rate on the effluent turbidity at $\mathrm{ds}=60 \mathrm{~cm} \& \mathrm{Co}=20 \mathrm{NTU}$.

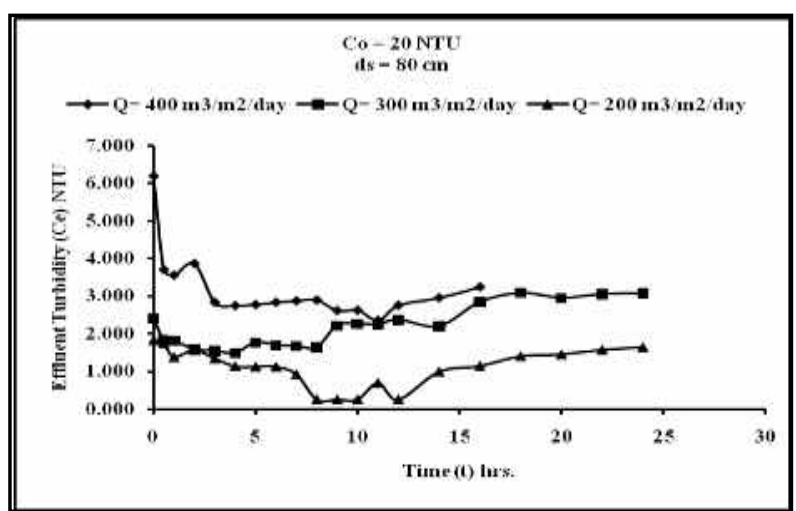

Fig. 7. Effect of filtration rate on the effluent turbidity at $\mathrm{ds}=80 \mathrm{~cm} \& \mathrm{Co}=20$ NTU. 


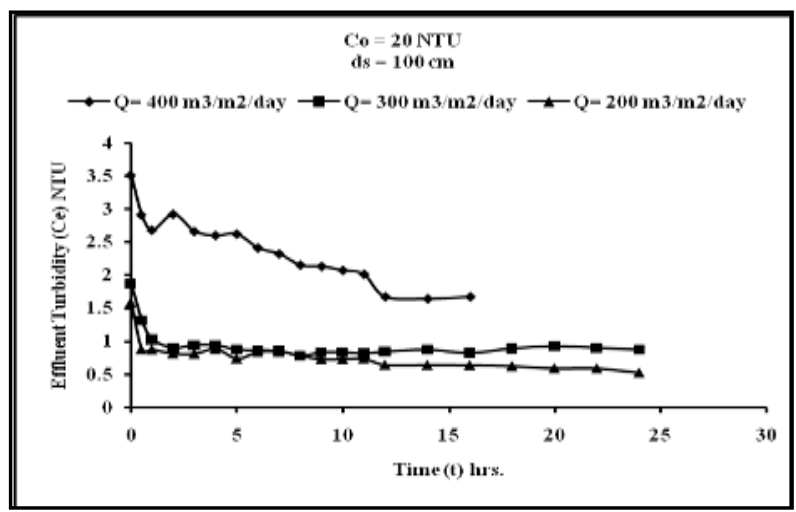

Fig. 8. Effect of filtration rate on the effluent turbidity at $\mathrm{ds}=100 \mathrm{~cm} \& \mathrm{Co}=20 \mathrm{NTU}$.

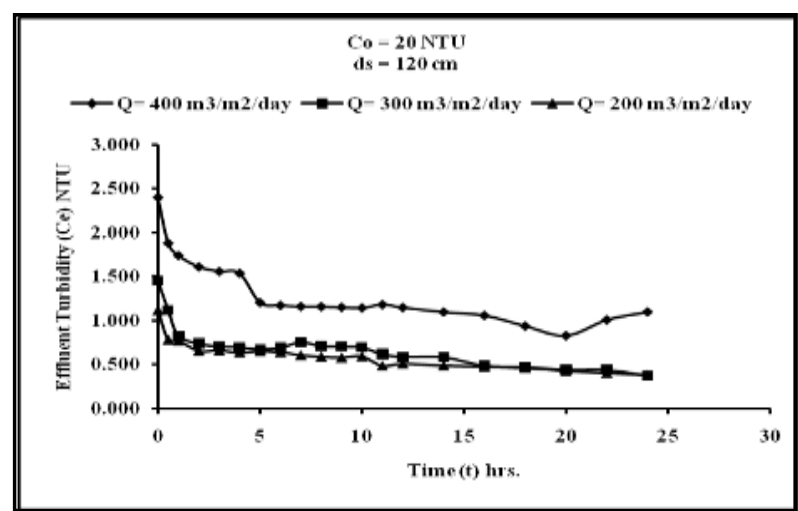

Fig. 9. Effect of filtration rate on the effluent turbidity at $\mathrm{ds}=120 \mathrm{~cm} \& \mathrm{Co}=20 \mathrm{NTU}$.

\subsubsection{Effect of sand depth}

The depth of media has significant effect on the effluent turbidity as shown in Fig. (10) to Fig. (15). As shown in Fig. (10), sand depth $80 \mathrm{~cm}$ is able to give acceptable effluent turbidity $\leq 1 \mathrm{NTU}$ for constant filtration rate $\leq 200 \mathrm{~m}^{3} / \mathrm{m}^{2} /$ day and influent turbidity $\leq 10$ NTU after about 2 hours. It was found that sand depth $100 \mathrm{~cm}$ is able to give acceptable effluent turbidity $\leq 1 \mathrm{NTU}$ for filtration rate $\leq 300 \mathrm{~m}^{3} / \mathrm{m}^{2} /$ day and effluent turbidity $\leq 20$ NTU after about 2 hours as shown in Figs. (10) to (13). Also it was found that sand depth $120 \mathrm{~cm}$ is able to give constant filtration rate $\leq 400 \mathrm{~m}^{3} / \mathrm{m}^{2} /$ day with acceptable effluent turbidity $\leq 1 \mathrm{NTU}$ at influent turbidity $\leq 10 \mathrm{NTU}$ as in Figure (14). From these Figures, it is noticed that, the effluent turbidity decreases with increase of the sand depth [1], for constant influent turbidity and filtration rate.

The reason is, by increasing the bed depth the available surface area increases for the capture of particulate matter. Thus, more particulate matter can be retained in the filtration bed, so the removal rate of the particulate matter is improved by increasing the bed depth.

The turbidity removal efficiency depends mainly of the sand depth for all the filtration rates and influent turbidities tested. The percentage increase in efficiency for high values of sand depths is not proportional economically with the percentage increase in sand depth. 


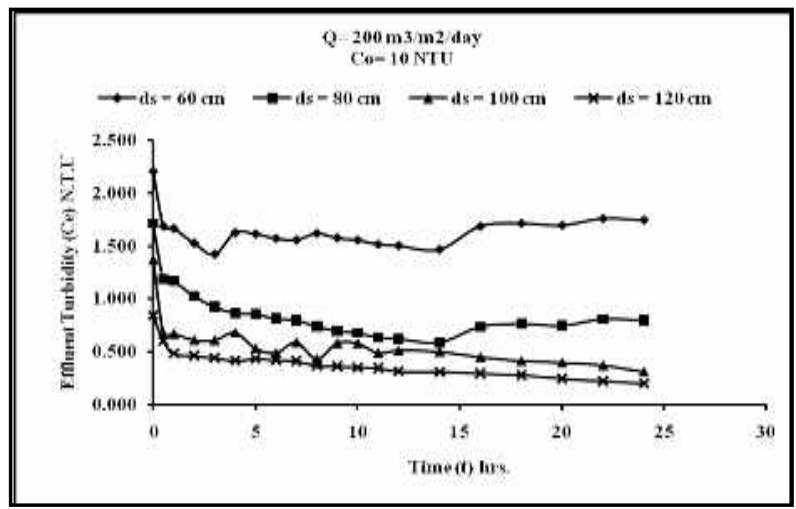

Fig. 10. Effect of sand depth with time on the effluent turbidity at Co $=10$ NTU $\& Q=200 \mathrm{~m}^{3} / \mathrm{m}^{2} /$ day.

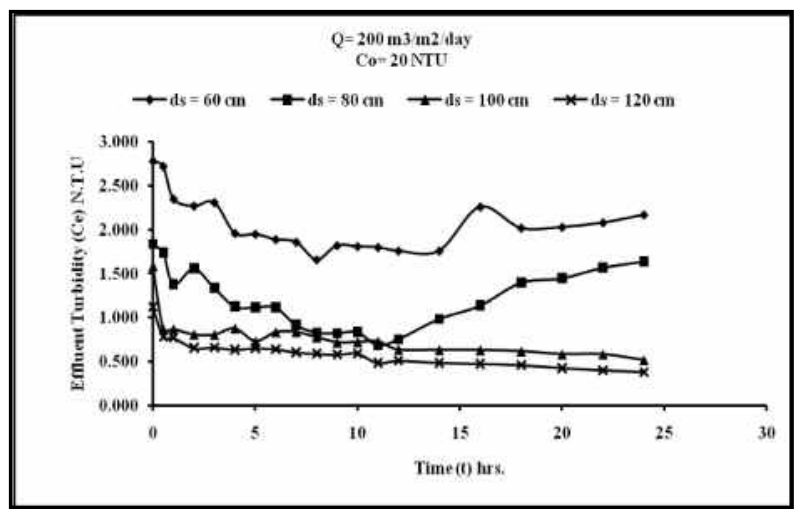

Fig. 11. Effect of sand depth with time on the effluent turbidity at Co $=20$ NTU $\& Q=200 \mathrm{~m}^{3} / \mathrm{m}^{2} /$ day.

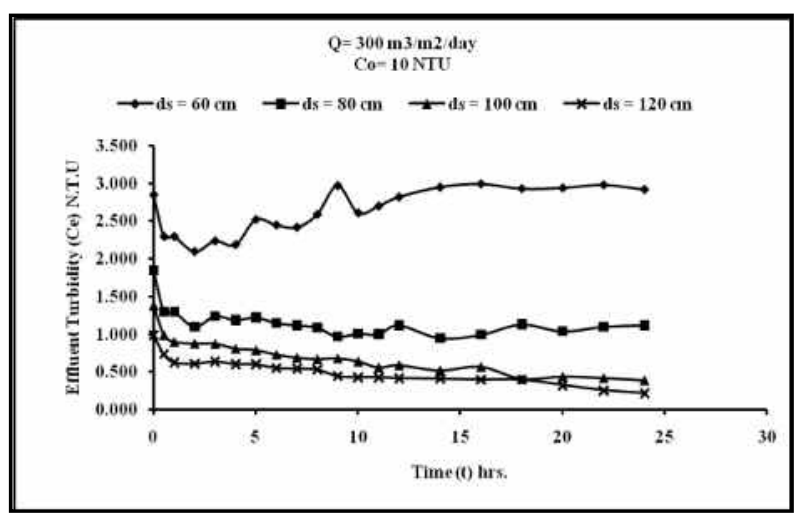

Fig. 12. Effect of sand depth with time on the effluent turbidity at Co $=10 \mathrm{NTU}$ $\& Q=300 \mathrm{~m}^{3} / \mathrm{m}^{2} /$ day. 


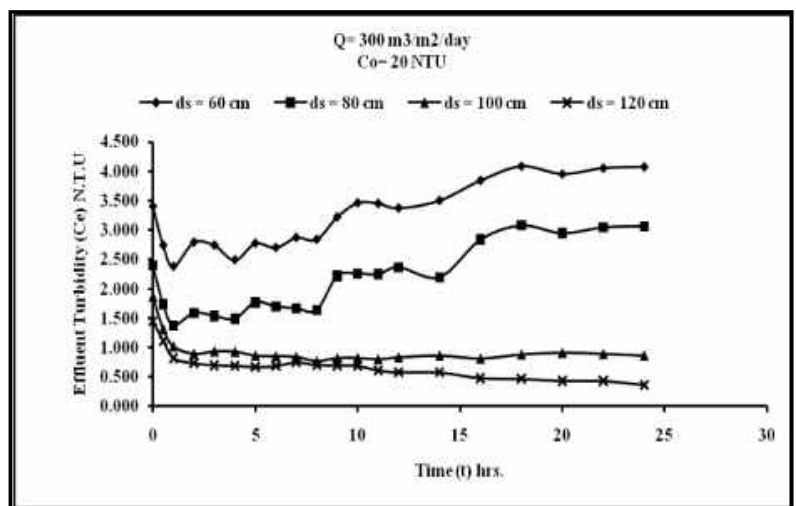

Fig. 13. Effect of sand depth with time on the effluent turbidity at Co $=20 \mathrm{NTU}$ $\& Q=300 \mathrm{~m}^{3} / \mathrm{m}^{2} /$ day.

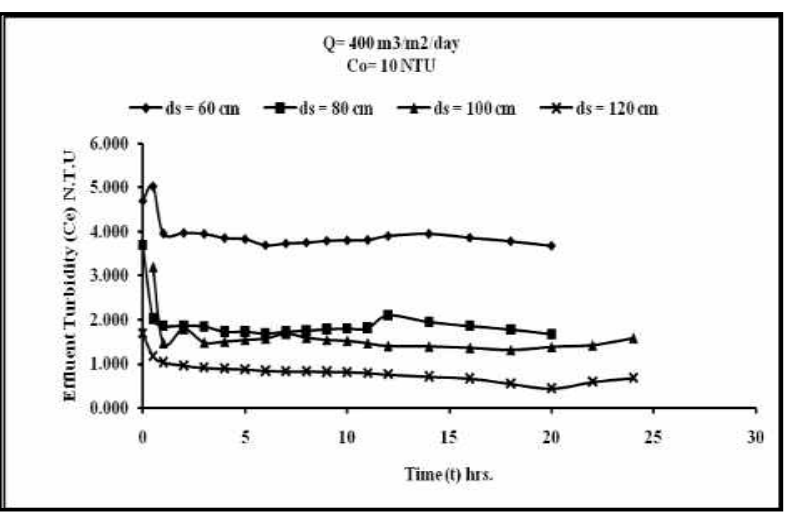

Fig. 14. Effect of sand depth with time on the effluent turbidity at Co $=10 \mathrm{NTU}$ $\& \mathrm{Q}=200 \mathrm{~m}^{3} / \mathrm{m}^{2} /$ day.

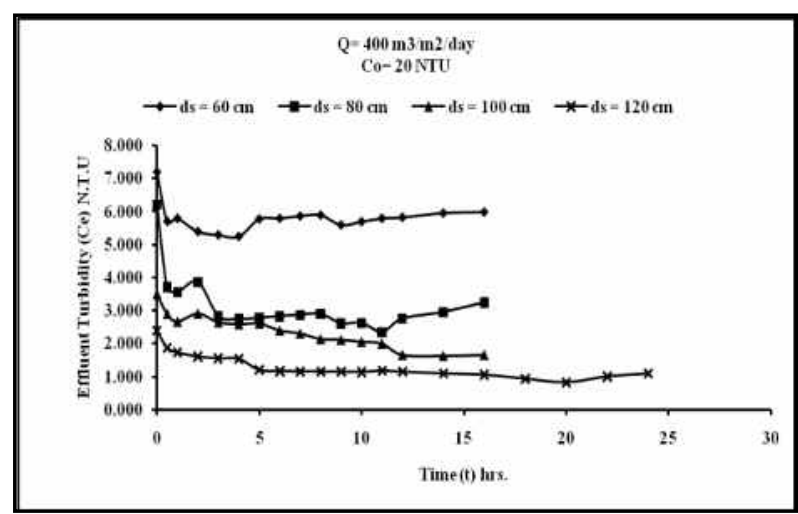

Fig. 15. Effect of sand depth with time on the effluent turbidity at Co $=10 \mathrm{NTU}$ $\& \mathrm{Q}=200 \mathrm{~m}^{3} / \mathrm{m}^{2} /$ day.

\subsubsection{Effect of influent turbidity}

In order to illustrate the effect of influent turbidity on the effluent turbidity, the results are plotted as shown in Fig. (16) to Fig.(21). From these Figures it is observed that at influent turbidity $\leq 20 \mathrm{NTU}$, depth $100 \mathrm{~cm}$ is able to give constant filtration rate $\leq 300$ $\mathrm{m}^{3} / \mathrm{m}^{2} /$ day with acceptable effluent turbidity $\leq 1$ NTU after about 2 hours as shown in Fig. 
(18). It was found that at influent turbidity $\leq 30 \mathrm{NTU}$, depth $120 \mathrm{~cm}$ is able to give constant filtration rate $\leq 300 \mathrm{~m}^{3} / \mathrm{m}^{2} /$ day with acceptable effluent turbidity $\leq 1 \mathrm{NTU}$ after about 2 hours for influent turbidity 30 and 20 NTU, and after about 0.5 hour for influent turbidity 10 NTU as shown in Figure (20). From Figs. (16) and (18), it is clearly noticed that for high influent turbidity (20 and $30 \mathrm{NTU}$ ), the effluent turbidity starts to increase again at a shorter time (after about 5 hours) than that for low influent turbidity (10 NTU). This may be explained by the fact that the speed of accumulation of particles through the pores of bed layer, then the suspended particles starts to escape with through the length of run water in big amount which explains the increase of effluent turbidity values with time. From these Figures, it's also clearly noticed that the effluent turbidity increases with the increase of influent turbidity for constant sand depth and filtration rate. This is due to at higher values of influent turbidity the carried amount of the suspended solids is high. Also, the effluent turbidity decrease slightly with time; and after about 1-2 hours, the effluent turbidity seems to be constant during the remaining time of the filtration run.

This is due to the first hours (after about 2 hours) of run, the bed is normally clean and the spacing between sand particles is large enough to pass most of suspended solids. But, with the time running, the individual particles may block the pores. So, as the porosity of the filter media decreases the effluent turbidity decreases until a certain time and the effluent turbidity increases again.

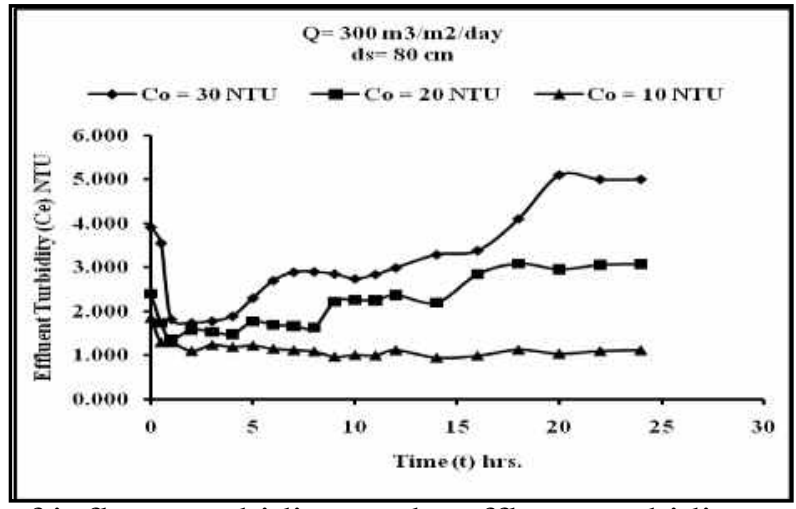

Fig. 16. Effect of influent turbidity on the effluent turbidity at $\mathrm{ds}=80 \mathrm{~cm} \& \mathrm{Q}=$ $300 \mathrm{~m}^{3} / \mathrm{m}^{2} /$ day.

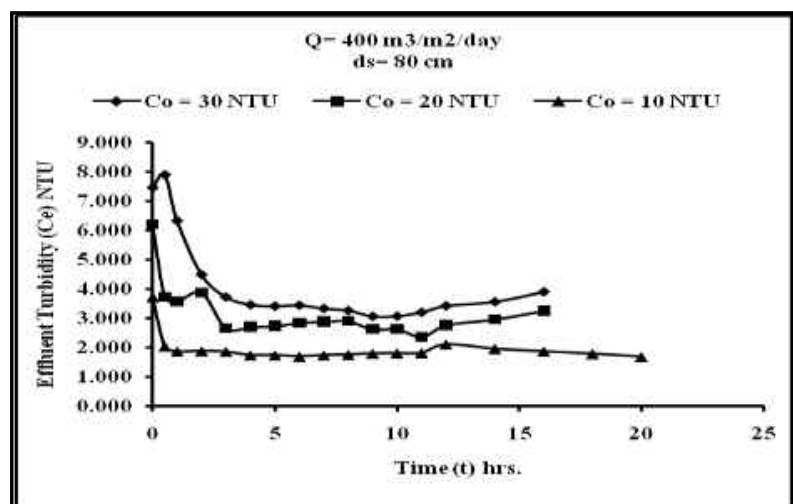

Fig. 17. Effect of influent turbidity on the effluent turbidity at $\mathrm{ds}=80 \mathrm{~cm} \& \mathrm{Q}=$ $400 \mathrm{~m}^{3} / \mathrm{m}^{2} /$ day. 


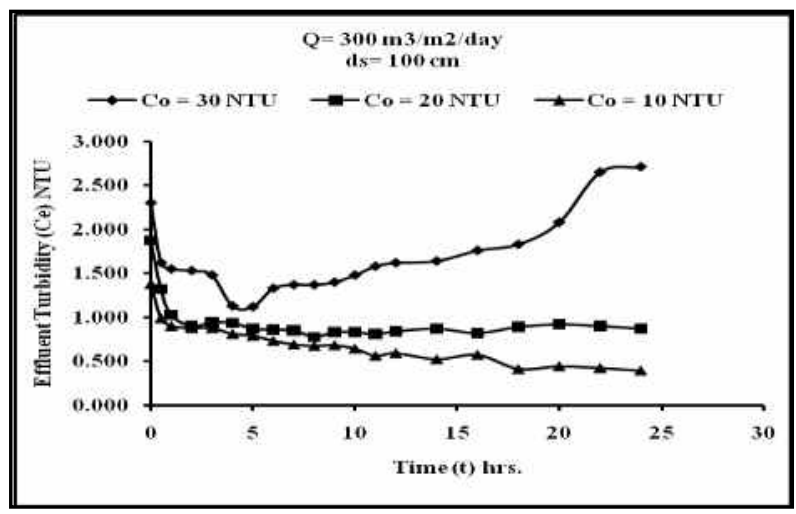

Fig. 18. Effect of influent turbidity on the effluent turbidity at $\mathrm{ds}=100 \mathrm{~cm} \& \mathrm{Q}$ $=300 \mathrm{~m}^{3} / \mathrm{m}^{2} /$ day.

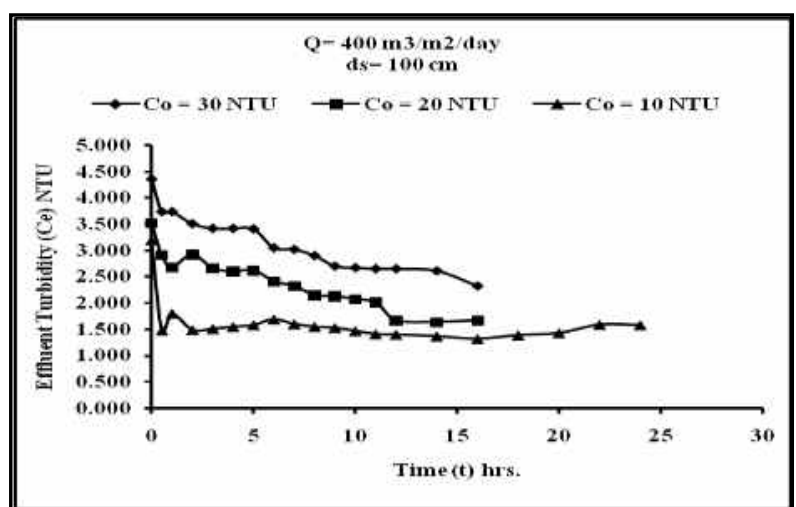

Fig. 19. Effect of influent turbidity on the effluent turbidity at ds $=100 \mathrm{~cm} \& \mathrm{Q}$ $=400 \mathrm{~m}^{3} / \mathrm{m}^{2} /$ day.

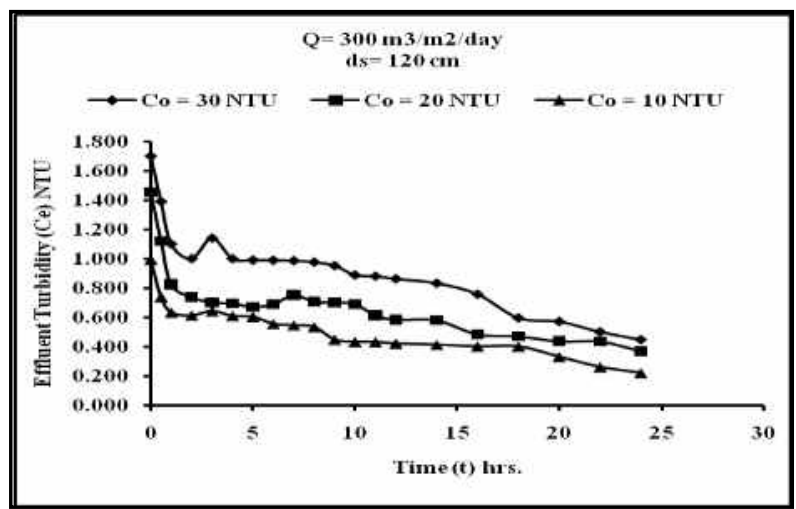

Fig. 20. Effect of influent turbidity on the effluent turbidity at ds $=120 \mathrm{~cm} \& \mathrm{Q}$ $=300 \mathrm{~m}^{3} / \mathrm{m}^{2} /$ day. 


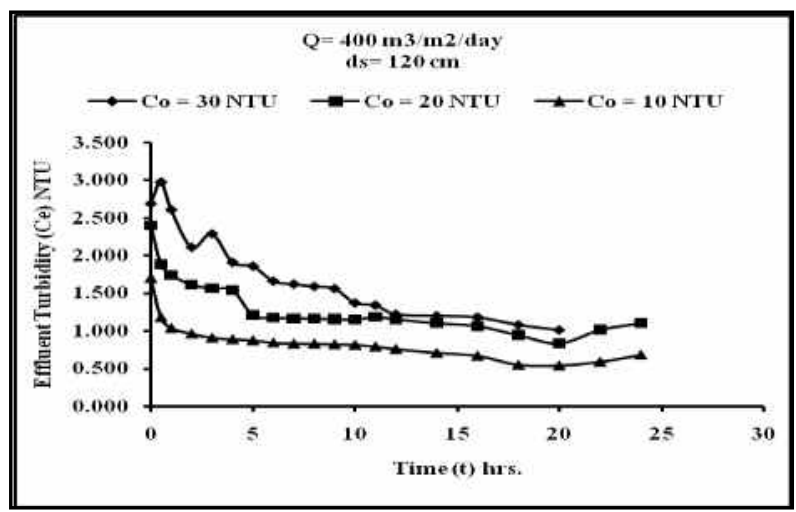

Fig. (21) Effect of influent turbidity on the effluent turbidity at ds $=120 \mathrm{~cm} \& \mathrm{Q}$ $=400 \mathrm{~m}^{3} / \mathrm{m}^{2} /$ day.

The parameters that influencing the effluent turbidity $(\mathrm{Ce})$ in the downflow filter are as follows:

The filtration rate $(\mathrm{Q})$, the media bed depth (ds), the influent turbidity $(\mathrm{Co})$ the media size (de) and the run time (t).

To obtain a general equation relating the effluent turbidity $(\mathrm{Ce})$ with the previous parameters the multiple regression equation can be expressed by the following formula:

$\mathrm{Ce}=\mathrm{m} 1 * \mathrm{t}+\mathrm{m} 2 * \mathrm{Co}+\mathrm{m} 3 * \mathrm{Q}+\mathrm{m} 4 * \mathrm{ds}+\mathrm{b}$

In which:

$\mathrm{Ce}=$ effluent turbidity

(NTU).

$\mathrm{m} 1, \mathrm{~m} 2, \mathrm{~m} 3, \mathrm{~m} 4$ and $\mathrm{b}=$ constant

(Dimensionless).

$\mathrm{t}=$ elapsed time

(hour).

Co $=$ influent turbidity

(NTU).

$\mathrm{Q}=$ filtration rate

(m/hour).

ds $=$ media depth

(m).

The above formula, Eqn. (3.1), can be written for the different values of media depths as follows;

For depth $\geq 100 \mathrm{~cm}$;

$\mathrm{Ce}=-0.04213 * \mathrm{t}+0.030146 * \mathrm{Co}+0.113052 * \mathrm{Q}-2.5321 * \mathrm{ds}+2.193$

For depth $<100$ cm;

$\mathrm{Ce}=0.028472 * \mathrm{t}+0.090571 * \mathrm{Co}+0.292799 * \mathrm{Q}-8.02822 * \mathrm{ds}+6.070$

\subsection{Filter head loss}

Measured clean filter head loss across the filter media as a function of filtration rate, sand depth and influent turbidity is shown in Figs. (22) to (39).

\subsubsection{Effect of filtration rate}

In order to study the effect of filtration rate $(\mathrm{Q})$ with time ( $\mathrm{t}$ ) on the total head loss $\left(\mathrm{H}_{\mathrm{L}}\right)$, the results are plotted against time for different sand depths and influent turbidities $(\mathrm{Co})$ as 
shown in Fig. (22) to Fig.(27). From these Figures it is observed that the total head loss value increases when the filtration rate is increased.

The fact that head loss increases with the filtration velocity $(V)$, particulate matter retained in the pores lead to a size decrease in the pores. The resistance of bed to the water flow will increase due to the size reduction of the pores. Increasing resistance with time increases the head loss.

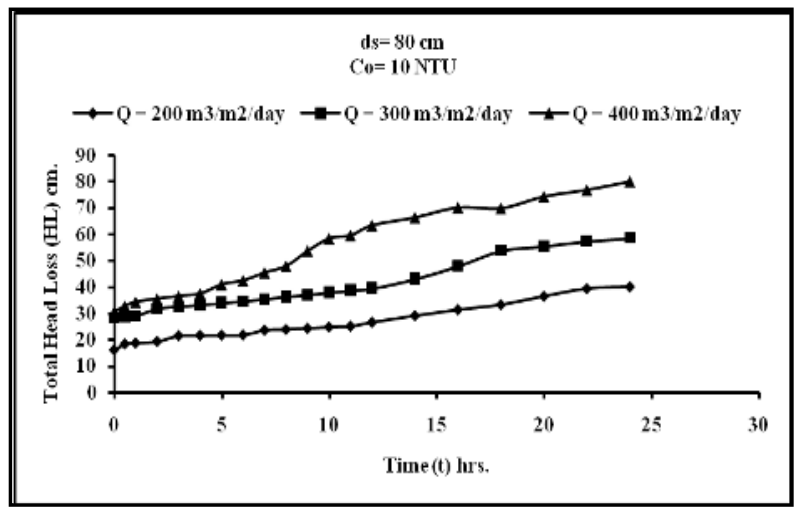

Fig. 22. Head loss against time for different filtration rates at $\mathrm{ds}=80 \mathrm{~cm} \& \mathrm{Co}=10 \mathrm{NTU}$.

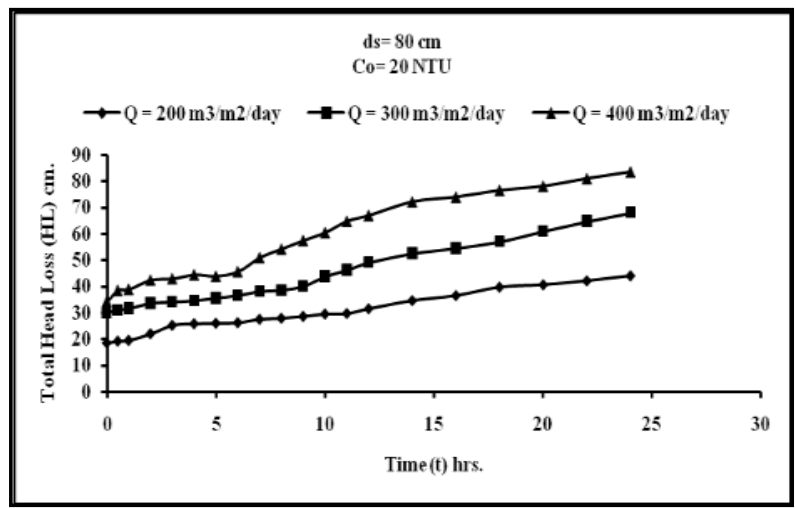

Fig. 23. Head loss against time for different filtration rates at $\mathrm{ds}=80 \mathrm{~cm} \& \mathrm{Co}=20 \mathrm{NTU}$.

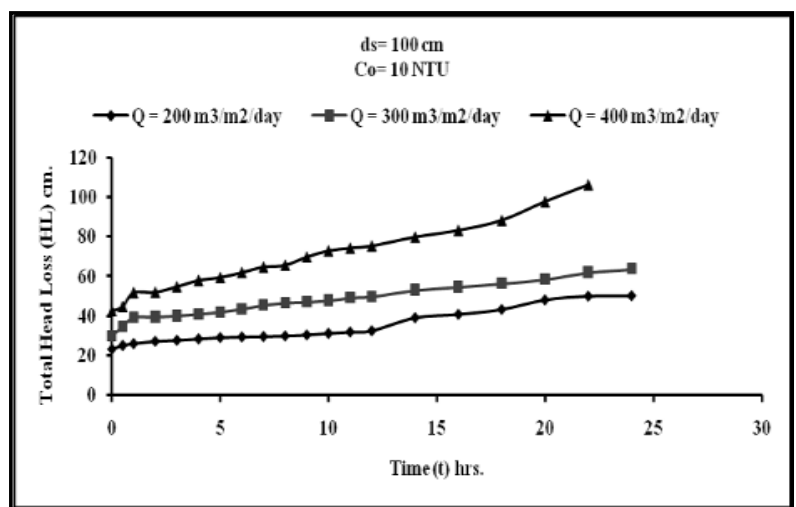

Fig. 24. Head loss against time for different filtration rates at $\mathrm{ds}=100 \mathrm{~cm} \&$ Co $=10$ NTU. 


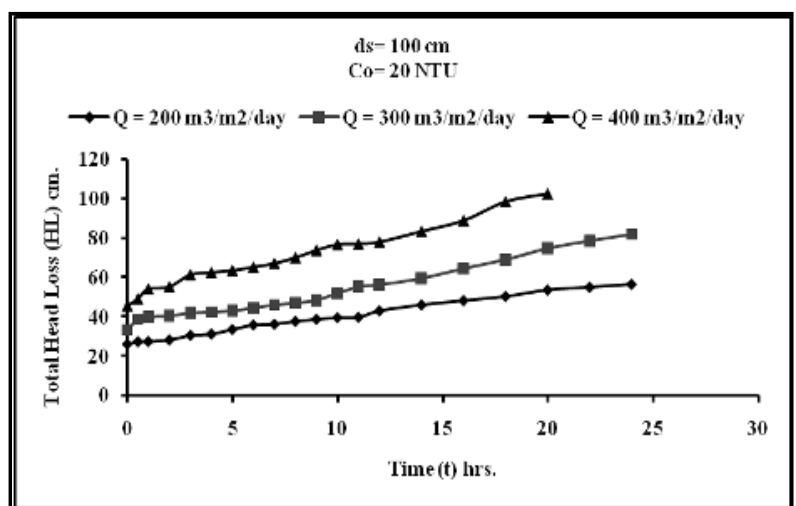

Fig. 25. Head loss against time for different filtration rates at $\mathrm{ds}=100 \mathrm{~cm} \& \mathrm{Co}=20$ NTU.

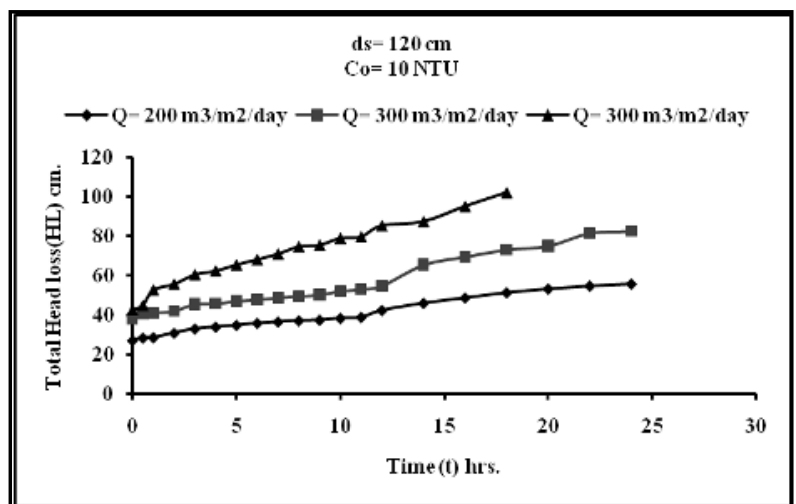

Fig. 26. Head loss against time for different filtration rates at $\mathrm{ds}=120 \mathrm{~cm} \& \mathrm{Co}=10$ NTU.

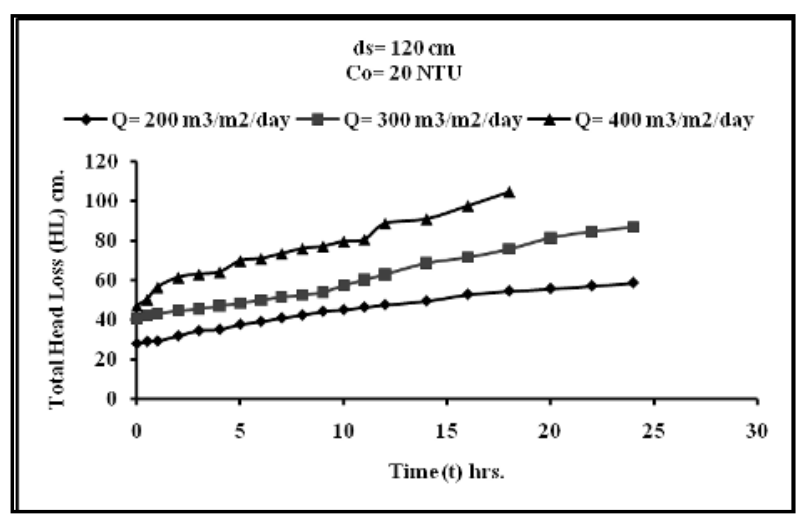

Fig. 27. Head loss against time for different filtration rates at $\mathrm{ds}=120 \mathrm{~cm} \& \mathrm{Co}=20$ NTU.

\subsubsection{Effect of sand depth}

In order to examine the effect of sand depth (ds) with time $(\mathrm{t})$ on the total head loss throughout the filter, the results are plotted as shown in Fig. (28) to Fig.(33) against time for different filtration rates (Q) and influent turbidities (Co). From these Figures it is 
clearly noticed that the total head loss value increases when the sand depth is increased. This may be due to decreasing of the porosity of the filter media with the time and the ability of penetration of suspended solids is decreasing with time as the porosity gets smaller. On the other hand, increasing the bed depth leads to an increase in friction force of the bed because of increasing surface area, and this causes an increase in head loss values.

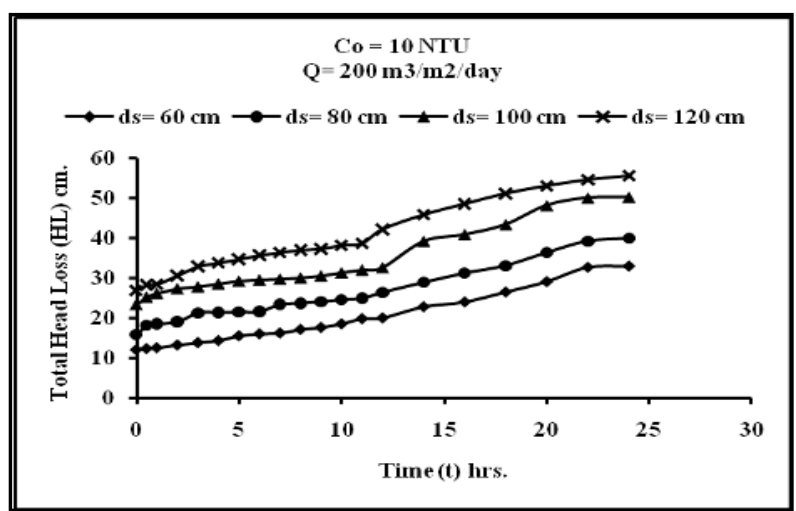

Fig. 28. Variation of head loss with time for different sand depths at Co $=10$ NTU \& Q $=200 \mathrm{~m}^{3} / \mathrm{m}^{2} /$ day.

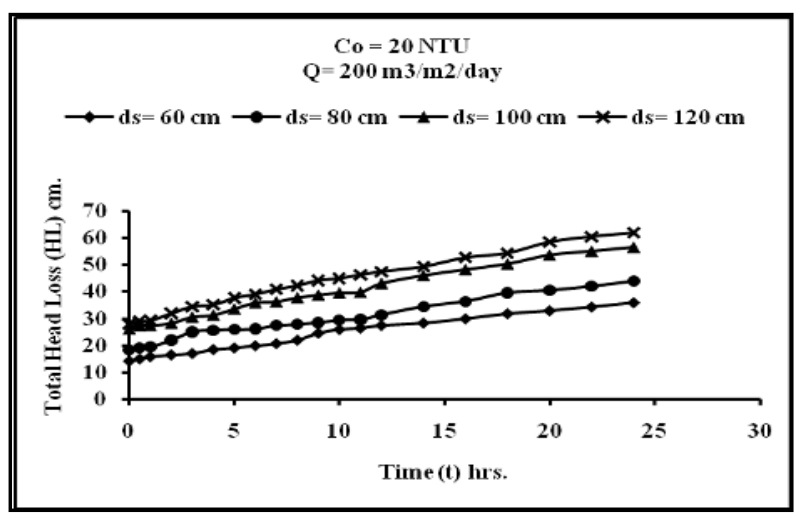

Fig. 29. Variation of head loss with time for different sand depths at Co $=10$ NTU \& Q $=200 \mathrm{~m}^{3} / \mathrm{m}^{2} /$ day.

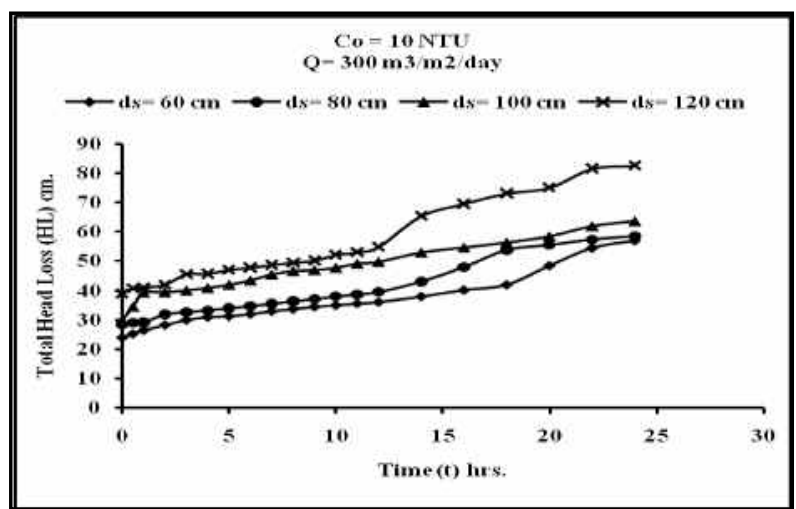

Fig. 30. Variation of head loss with time for different sand depths at Co $=10$ NTU \& Q $=200 \mathrm{~m}^{3} / \mathrm{m}^{2} /$ day. 


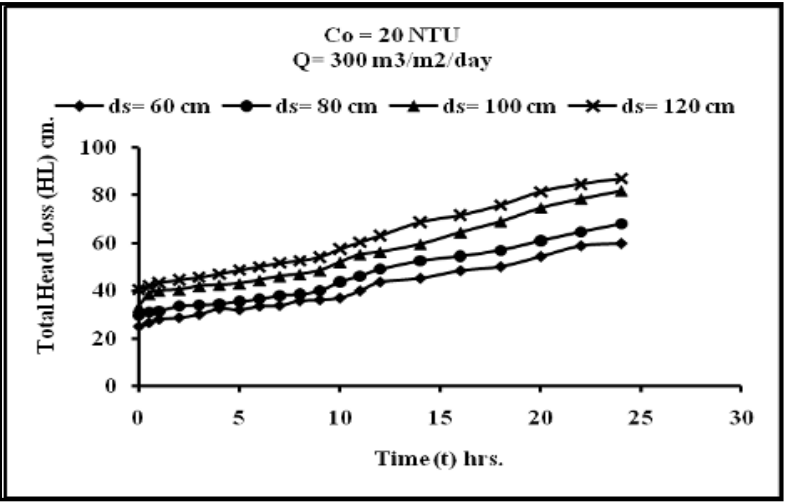

Fig. 31. Variation of head loss with time for different sand depths at Co $=10$ NTU \& Q $=200 \mathrm{~m}^{3} / \mathrm{m}^{2} /$ day.

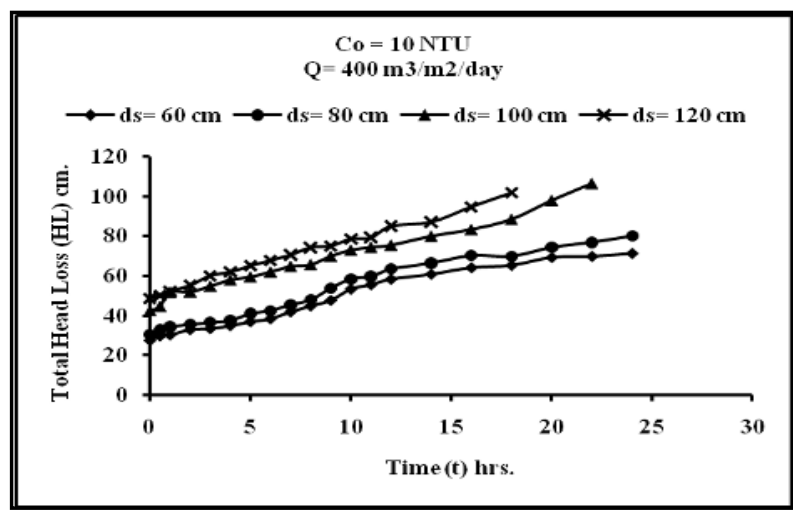

Fig. 32. Variation of head loss with time for different sand depths at Co $=10$ NTU \& $\mathrm{Q}=200 \mathrm{~m}^{3} / \mathrm{m}^{2} /$ day.

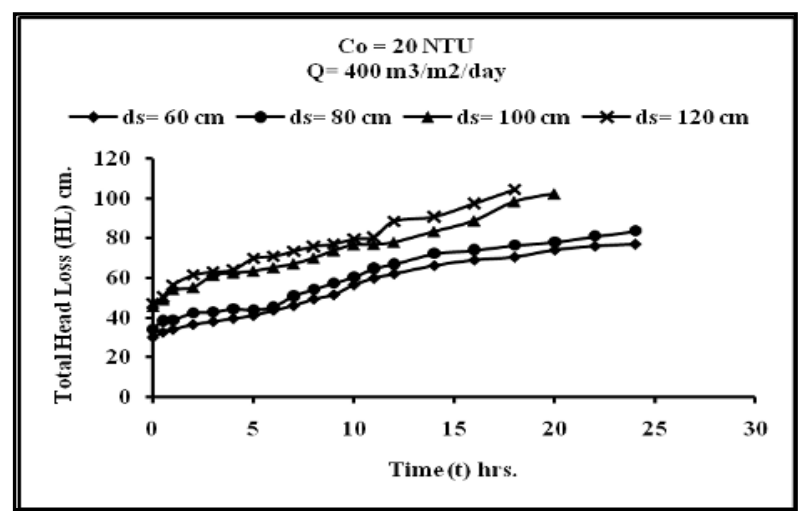

Fig. 33. Variation of head loss with time for different sand depths at $\mathrm{Co}=10$ NTU \& $\mathrm{Q}=200 \mathrm{~m}^{3} / \mathrm{m}^{2} /$ day.

\subsubsection{Effect of influent turbidity}

In order to illustrate the effect of influent turbidity $(\mathrm{Co})$ on the total head loss $\left(\mathrm{H}_{\mathrm{L}}\right)$, the experimental results are plotted against time (t) for different sand depths and filtration rates (Q) as shown in Fig. (34) to Fig.(39), it is clearly noticed that the total head loss value 
624

Haitham M. Amin and A. A. Mohamed, Effect of some parameters on performance of ...........

increases when the influent turbidity is increased. This is due to at higher values of influent turbidity the carried amount of the suspended solids is high. The porosity of the filter media is then decrease with time and blockage of the filter occurs rapidly than that at smaller values of influent turbidity. Knowing that the head loss is a function of the porosity of the filter media the head loss increase as the porosity decreases.

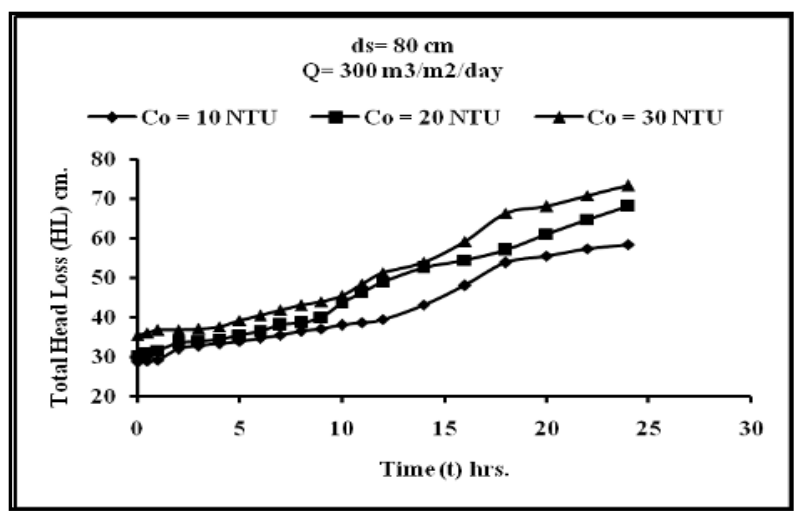

Fig. 34. Variation of head loss with time for different influent turbidities at $\mathrm{ds}=$ $80 \mathrm{~cm} \& \mathrm{Q}=300 \mathrm{~m}^{3} / \mathrm{m}^{2} /$ day.

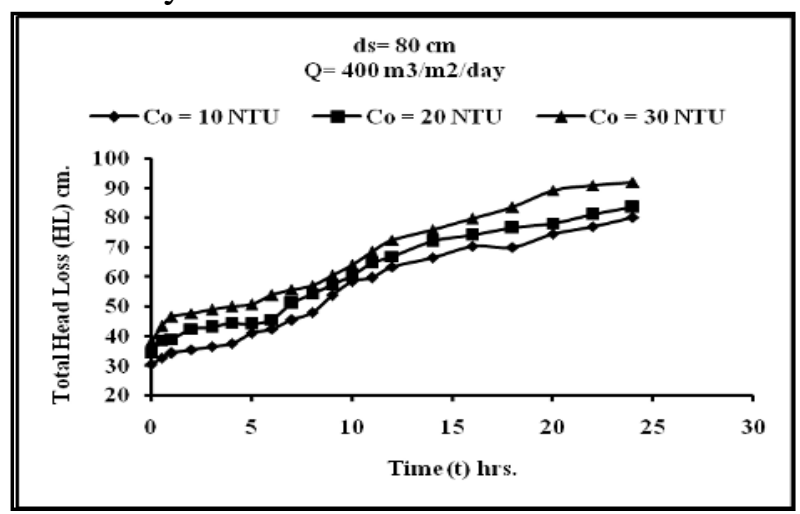

Fig. 35. Variation of head loss with time for different influent turbidities at $\mathrm{ds}=$ $80 \mathrm{~cm} \& \mathrm{Q}=300 \mathrm{~m}^{3} / \mathrm{m}^{2} /$ day.

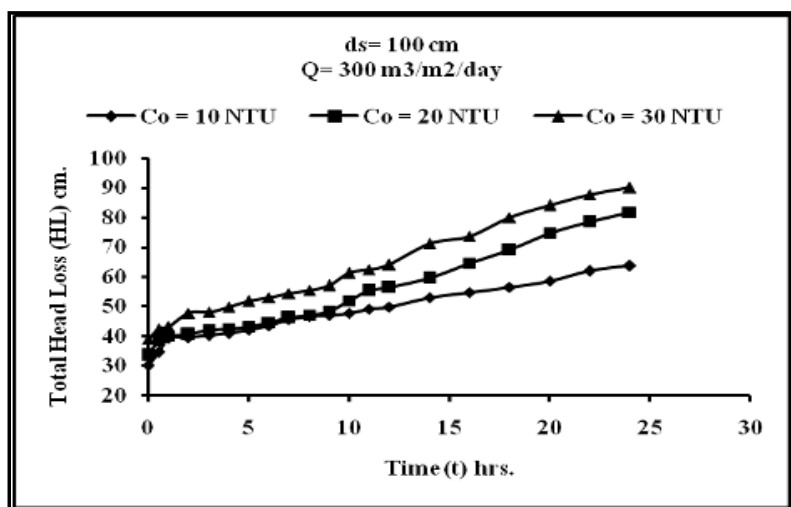

Fig. 36. Variation of head loss with time for different influent turbidities at $\mathrm{ds}=$ $80 \mathrm{~cm} \& \mathrm{Q}=300 \mathrm{~m}^{3} / \mathrm{m}^{2} /$ day. 


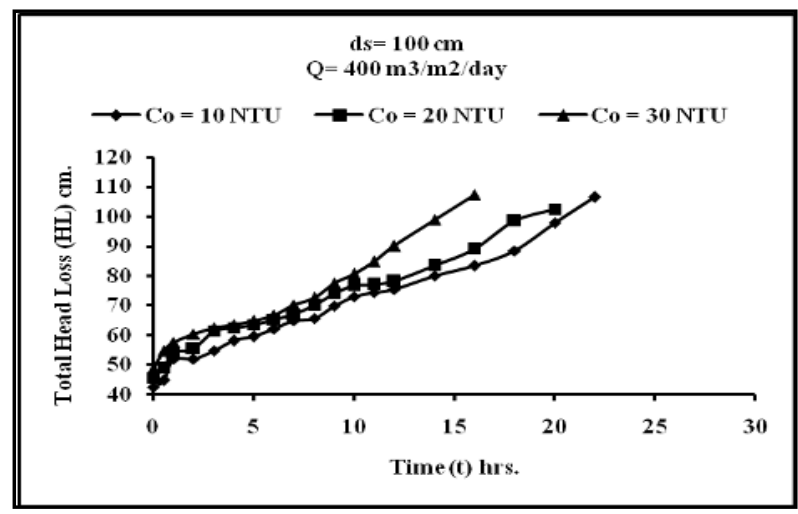

Fig. 37. Variation of head loss with time for different influent turbidities at ds $=$ $80 \mathrm{~cm} \mathrm{\&} \mathrm{Q}=300 \mathrm{~m}^{3} / \mathrm{m}^{2} /$ day.

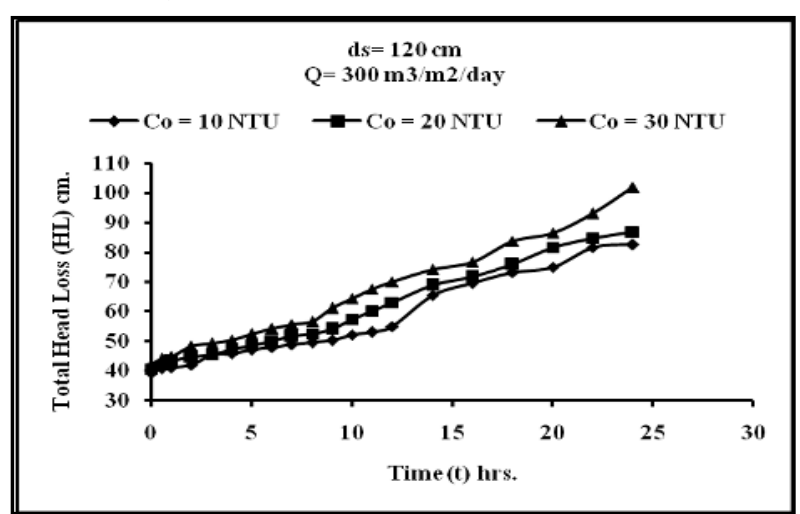

Fig. 38. Variation of head loss with time for different influent turbidities at ds $=$ $80 \mathrm{~cm} \& \mathrm{Q}=300 \mathrm{~m}^{3} / \mathrm{m}^{2} /$ day.

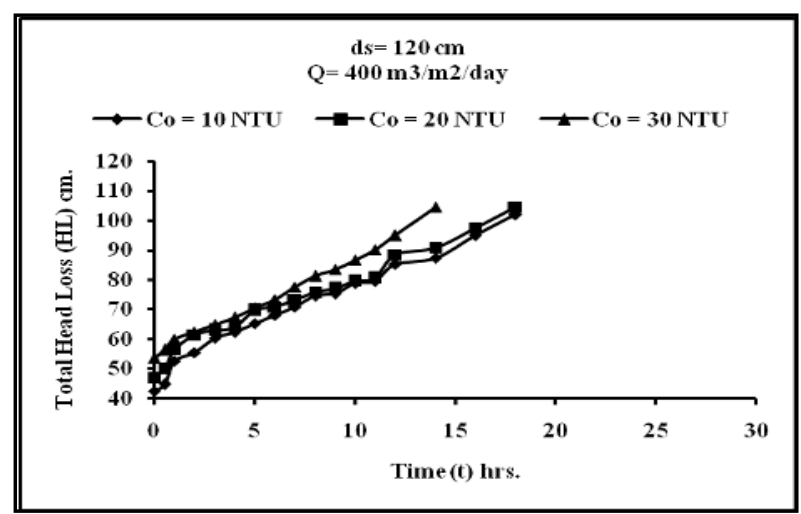

Fig. (39) Variation of head loss with time for different influent turbidities at ds = $80 \mathrm{~cm} \& \mathrm{Q}=300 \mathrm{~m}^{3} / \mathrm{m}^{2} /$ day. 


\section{Conclusions}

From this study it was found that:

1. Sand depth of $120 \mathrm{~cm}$ is able to give a constant filtration rate from 200 to 400 $\mathrm{m}^{3} / \mathrm{m}^{2} /$ day with acceptable quality $(\leq 1 \mathrm{NTU})$ for values of influent turbidity $\leq 10$ NTU.

2. Sand depth $80 \mathrm{~cm}$ is able to give acceptable effluent turbidity $\leq 1$ NTU for constant filtration rate $\leq 200 \mathrm{~m}^{3} / \mathrm{m}^{2} /$ day and influent turbidity $\leq 10 \mathrm{NTU}$.

3. Sand depth $100 \mathrm{~cm}$ is able to give acceptable effluent turbidity $\leq 1$ NTU for filtration rate $\leq 300 \mathrm{~m}^{3} / \mathrm{m}^{2} /$ day and effluent turbidity $\leq 20 \mathrm{NTU}$.

4. For influent turbidity $\leq 10 \mathrm{NTU}$, the sand depth $120 \mathrm{~cm}$ is more suitable for rate $\leq$ $400 \mathrm{~m}^{3} / \mathrm{m}^{2} /$ day, the sand depth $100 \mathrm{~cm}$ is more suitable for rate $\leq 300 \mathrm{~m}^{3} / \mathrm{m}^{2} /$ day and the sand depth 80 is more suitable for rate $\leq 200 \mathrm{~m}^{3} / \mathrm{m}^{2} /$ day.

5. For influent turbidity $\leq 20 \mathrm{NTU}$, the sand depth $100 \mathrm{~cm}$ is more suitable for constant filtration rate $\leq 300 \mathrm{~m}^{3} / \mathrm{m}^{2} /$ day.

6. For influent turbidity $\leq 30 \mathrm{NTU}$, the sand depth $120 \mathrm{~cm}$ is more suitable for constant filtration rate $\leq 300 \mathrm{~m}^{3} / \mathrm{m}^{2} /$ day.

7. The depth of the filter media has significant effect on the effluent turbidity, head loss, and run length. It was found that by increasing the depth of the filter media both the run length and the effluent turbidity decrease. Also, head loss increases.

8. The influent turbidity has a great influence on the run length, effluent turbidity and head loss. By increasing the influent turbidity, both the effluent turbidity and head loss increase, on the other hand the run length decreases.

9. The filtration rate has a great effect on the effluent turbidity, head loss and run length. It was found that by increasing the filtration rate the effluent turbidity, head loss increase and the run length decreases.

10.The relation between the effluent turbidity and the previous variables can be given in the following form:

For depth $\geq 100 \mathrm{~cm}$;

$$
\mathrm{Ce}=-0.04213 * \mathrm{t}+0.030146 * \mathrm{Co}+0.113052 * \mathrm{Q}-2.5321 * \mathrm{ds}+2.193
$$

For depth < $100 \mathrm{~cm}$;

$$
\mathrm{Ce}=0.028472 * \mathrm{t}+0.090571 * \mathrm{Co}+0.292799 * \mathrm{Q}-8.02822 * \mathrm{ds}+6.070
$$

The results from pilot Model can be applied directly to actual field.

\section{REFERENCES}

[1] Abdel-Gawad, A. M., 2005. "Experimental Investigation of Some Factors Affecting the Direct Upflow Filtration for Potable Water", M. Sc. thesis, Assiut University, Assiut, Egypt.

[2] Altunkaynak, A., 2010. Suspended Sediment Concentration Prediction by Geno-Kalman Filtering. Expert Syst. 37, 8583-8589.

[3] American Water Works (AWWA), 2003. Principals and Practices of Water Supply Operations: Water Treatment, Third ed. American Water Works Association, Denver, Colorado.

[4] Australia, W., 2002. National Technical Manual. Module 4: Physical and Chemical Parameters. Water watch Australia Steering Committee Environment Australia. 
[5] Aziz, S. Q. 2009. Treatment of Greater-Zab Water by Direct Filtration. Thirteenth International Water Technology Conference, IWTC 13 2009, Hurghada, Egypt.

[6] Gitis, V., Rubinstein, I., Livshits, M., Ziskind, G., 2010. Deep-bed Filtration Model with Multistage Deposition Kinetics. Chem. Eng. J. 163, 78-85.

[7] Haman, D.Z., Smajstrla, A.G., Zazueta, F.S., 1994. Media Filters for Trickle Irrigation in Florida. AE57, Agricultural and Biological Engineering Department, Florida Cooperative Extension Service, Institute of Food and Agricultural Sciences, University of Florida, Gainesville, FL.

[8] Huck, P.M.; Coffey, B.M.; Emelko, M.B.; Maurizio, D.D.; Slawson, R.M.; Anderson,W.B.; Van Den Oever, J.; Douglas, I.P.; and O'melia, C.R. (2001) Effects of Filter Operation on Cryptosporidium Removal. Journal AWWA 94(6), 97-111.

[9] Kawamura S. (2000). Integrated Design and Operation of Water Treatment Facilities. Second Edition, John Wiley \& Sons Inc.

[10] Mulligan. C. N., Davarpanah. N., Fukue. M., Inoue. T., 2009. "Filtration of Contaminated Suspended Solids for the Treatment of Surface Water. Chemosphere 74, 779-786.

[11] Myre. E., Shaw, R., Candidates, M., 2006. The Turbidity Tube: Simple and Accurate Measurement of Turbidity in the Field. Michigan technology University, Michigan, 12.

[12] Nakayama, F.S., Boman, B.J., Pitts, D.J., 2007. Maintenance In: Lamm, F.R., Ayars, J.E.,Nakayama, F.S. (Eds.), Microirrigation for Crop Production: Design, Operation, and Management, Developments in Agricultural Engineering, vol.13. Elsevier, Amsterdam, pp. 389-430.

[13] Phillips, K.P., 1995. Long-term operation of microirrigation filtration systems; success, failures and operational solutions. In: Proceedings of the Fifth International Irrigation Congress, Orlando, FL, pp. 579-585.

[14] Pitts, D.J., Haman, D.Z., Smajstrla, A.G., 1990. Causes and prevention of emitter plugging in microirrigation system. Bulletin 258. Florida Cooperative Extension Service, Institute of Food and Agriculture Science, University of Florida, Gainesville, FL. 


\section{تأثير بعض العوامل على أداء الترشيح المباشر عالى المعدل فى تنقية المياه}

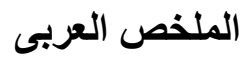

المياه هى أساس الحياة ، وبدونها لايكون للحياة وجود ـ ومعظم هذه المباه بشكلها الطبيعي لا تعتبر صالحة

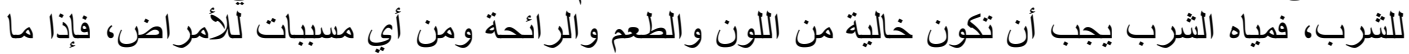

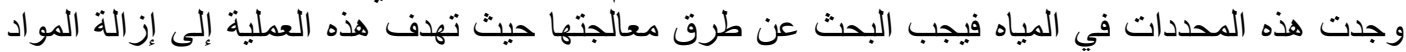

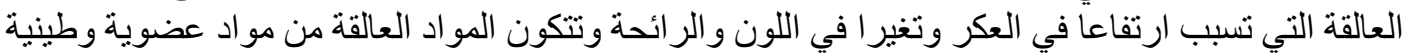

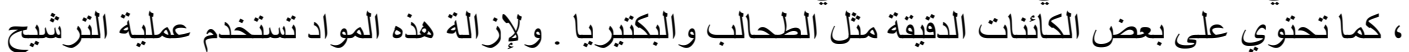
باستخدام مرشحات رملية. الترشيح المباشر عبارة عن دخول المياه مباشرة على المرشحات دون المرور على على علية الترويب

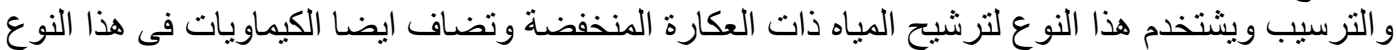

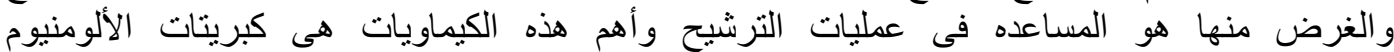

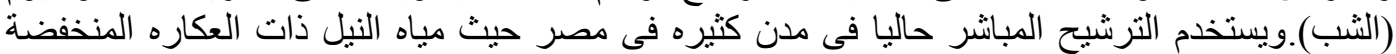

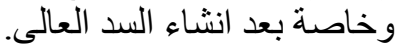

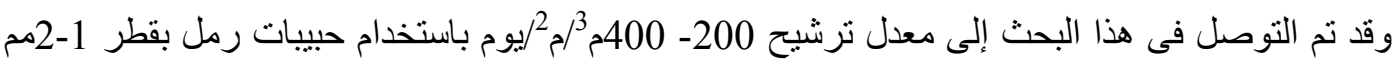

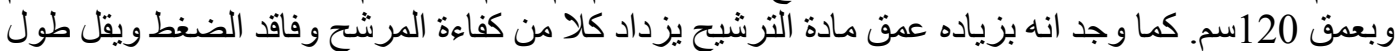

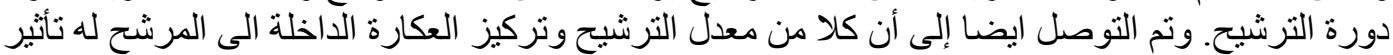

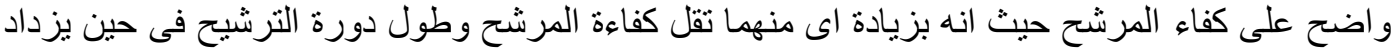

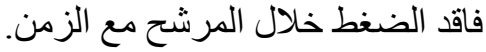

